\title{
INVESTIGATION OF NEW DRUGS, WITH SPECIAL REFERENCE TO LARGACTIL (CHLORPROMAZINE, THORAZINE R.P. 4560, M \& B 2378, 2601A S K.F ) AS AN EXAMPLE*
}

\author{
R. G. B. Grbert, M D., F.R C P.(C), D.A., Allan B. Dobkin, M.D., \\ and Louis LamoureuX, M.D. ${ }^{*}$
}

MANY anaesthetists, mcluding one of the authors (1) have been advocating, if not a return to simpler forms of anaesthetic procedure, then the use of techniques and drugs with care and thought concerning morbidity. A timely comment, such as that written by Dr. Langton Hewer entitled "Whither Anaesthesia" (2), should lead to caution being exercised by the more rabid members of our specialty.

How can such views be reconcled with those expressed by many, that modern anaesthesia is an ald to modern major surgery, without which many operations could not be performed? The answer is, of course, that progress can be made with the maintenance of conservative thought and by carrying out research along fairly well formed, traditional lines.

New techniques, drugs, and ideas corne and go. They may even be rediscovered; in this connection Gillespie (3) has reminded us of Bernard Shaw's Doctor's Dilemma. Eventually, however, with the appreciation of merit, such innovations find their own level. Once accepted, they are assigned the timehonoured qualifications. Indications, contrandications and complications.

Such concepts have governed investigations recently reported from our Department $(4,5,6,7)$.

When a group of new drugs or a new member of a group is presented to our specialty, should it be accepted as advertised and used on the evidence of clinical impression? Some may, if extensive clinical trial and laboratory research by others warrant it. In this case they should be introduced with caution and in the presence of avallable knowledge to corr pete with complications.

What happens if a panacea be graspec. without fair trial? An example may be given in the use of Efocame, following which serious complications, the possibility of which were at first dened, have occurred $(8,9)$.

What is desired of a New Drug?

1. A new drug must have a desirable specific action. It should not be assessed according to its portion in a cocktail (10).

2. It must be of low toxicity.

3. It must possess controllability and reversability.

4. It must present few complications.

5. It must be possible to deal rationally and. easily with such complications.

'Presented at the Annual Meetıng, Canadian Anaesthetısts' Society, Vancouver, British Columbia, June 14-15, 1954

* From Queen Mary Veterans' Hospital, Montreal, McGill University and Université de Montréal 
If these conditions are fulfilled, then it must be proven that the new drug is at least as good as, if not superior to, any pre-existing counterparts. To these conditions should be added, ease of production and cost. In the words of Dr. Harold Griffith when discussing relaxant drugs, "D-Tubo Curare will not be replaced until something better can be discovered, then given full and satisfactory clinical trial."

\section{INVESTIGATIONS}

Drugs may be investigated in a number of ways; in anaesthesia relatively accurate data can be obtained.

The agents can be given to a normal volunteer, once they have passed the animal stage. They can then be given clinical trial and used in pathological states.

Animal experimentation yields much information but accurate inferences cannot always be made owing to differences between species.

From combined evidence, so deduced, the mode of action of the drug is sought; likewise it is evaluated.

Figure 1
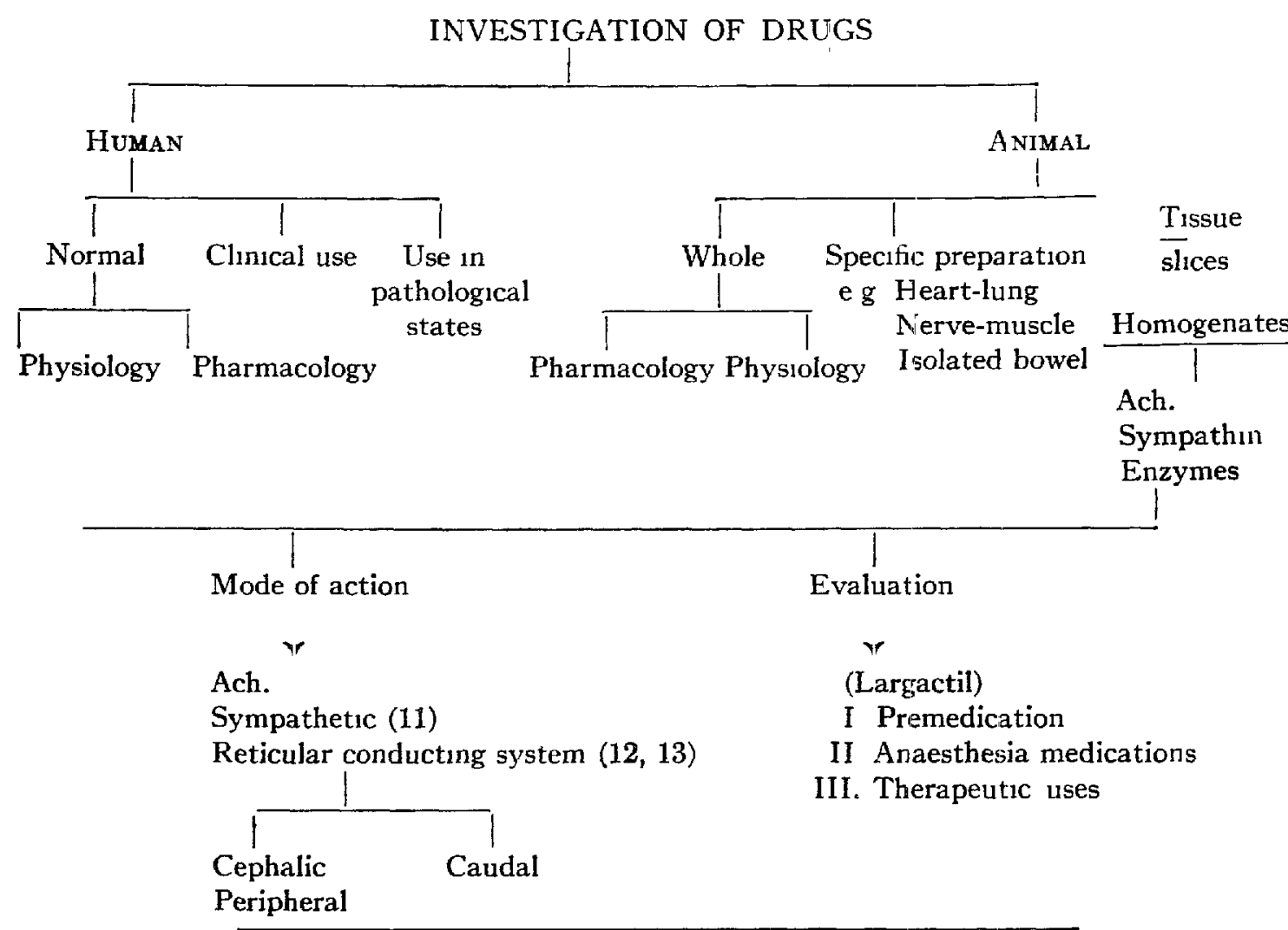

Figure 2 is an endeavour to illustrate some of the observations and investigations which can readily be carried out. They can be divided into those affecting the cardiovascular system, the respiratory system, and so forth.

The action of the greatest proportion of the drugs which are used in anaesthesia is mediated by the nervous system, Therefore special note must be made of the effects of the drug upon it. 

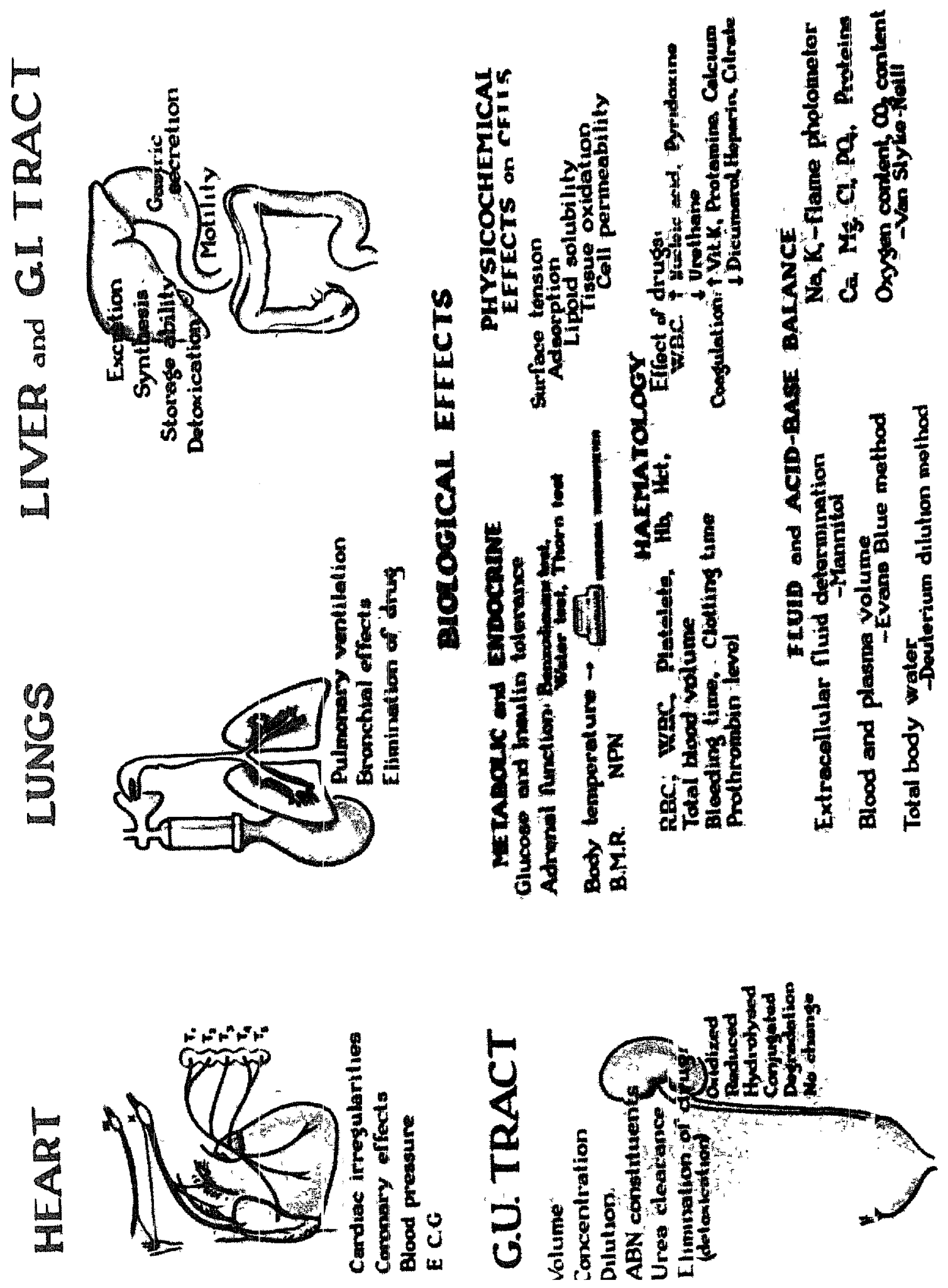
In Figure 3 may be seen charts of Paton (14) concerning neuromuscular block and of Adriani (15) when he systematically describes the pharmacology of anaesthetic drugs. This diagram emphasizes the close relationship between our clinical specialty and the basic sciences upon which it is based.

In a previous paragraph attention was drawn to the action of drugs upon the central nervous system. With the growing development and use of blocking agents which act at different levels, study of this action becomes more importan:; if the anaesthetist is to have at least a working knowledge of the drugs at his command. Figure 4 is an attempt to show the possible effects upon specific portions of the nervous system and to give examples of drugs which call forth such a response. More detailed nervous structures and conducting systems have been omitted.

While a drug is being studied, specific pathological effects must be given constant observation. Is that drug irritant, when taken by mouth? Does it produce thrombosis when given intravenously? Does it give rise to tissue necrosis when given intramuscularly or subcutaneously? What is its minimal lethal dose? Figure 5 classifies some of the possible complications which may be anticipated. Consideration must be given to all of these and more besides before a satisfactory review can be made.

\section{LARGACTIL}

The Department of Anaesthesia at Queen Mary Veterans' Hospital, arded by a Fellow in Anaesthesia, Dr. Allan B Dobkın, and nany of the resources at that Institution, has recently undertaken studies with Largactul. These studies have been published elsewhere (5)

During the work, some systems proved more easy of investıgation than others, and were at the same time of great importance Hence, much time was spent on the respiratory system and on metabohsm. One reason for this was the report that Largactil stimulated respiration, this being a deduction from animal experimentation. Our results showed that although the respiration rate may be increased, the minute volume is considerably decreased. It was also shown that metabolism, as measured by oxygen consumption, was not depressed.

\section{Sympathetic Nervous System}

Early in our studies, which actually commenced with hypothermia in view, it became evident that the hypothermia was brought about by marked peripheral syasodilatation. This fact has been used in the investigation of peripheral vascular disease (6).

Temperature studies, made with a universal thermometer, carrying ten electrodes, showed that Largactil produces a peripheral response equal to that induced by lumbar sympathetic block or spinal anaesthesia.

The importance of the use of Largactil in this field for both diagnostic and therapeutic purposes may be considered.

That Largactil is a potent depressor of the sympathetic nervous system is proven, though the actual site of the depression is open to debate. Another factor in this connection is the pin point pupil which may be noted following the use of Largactil. This may be equal in calibre to that produced by Morphine. 

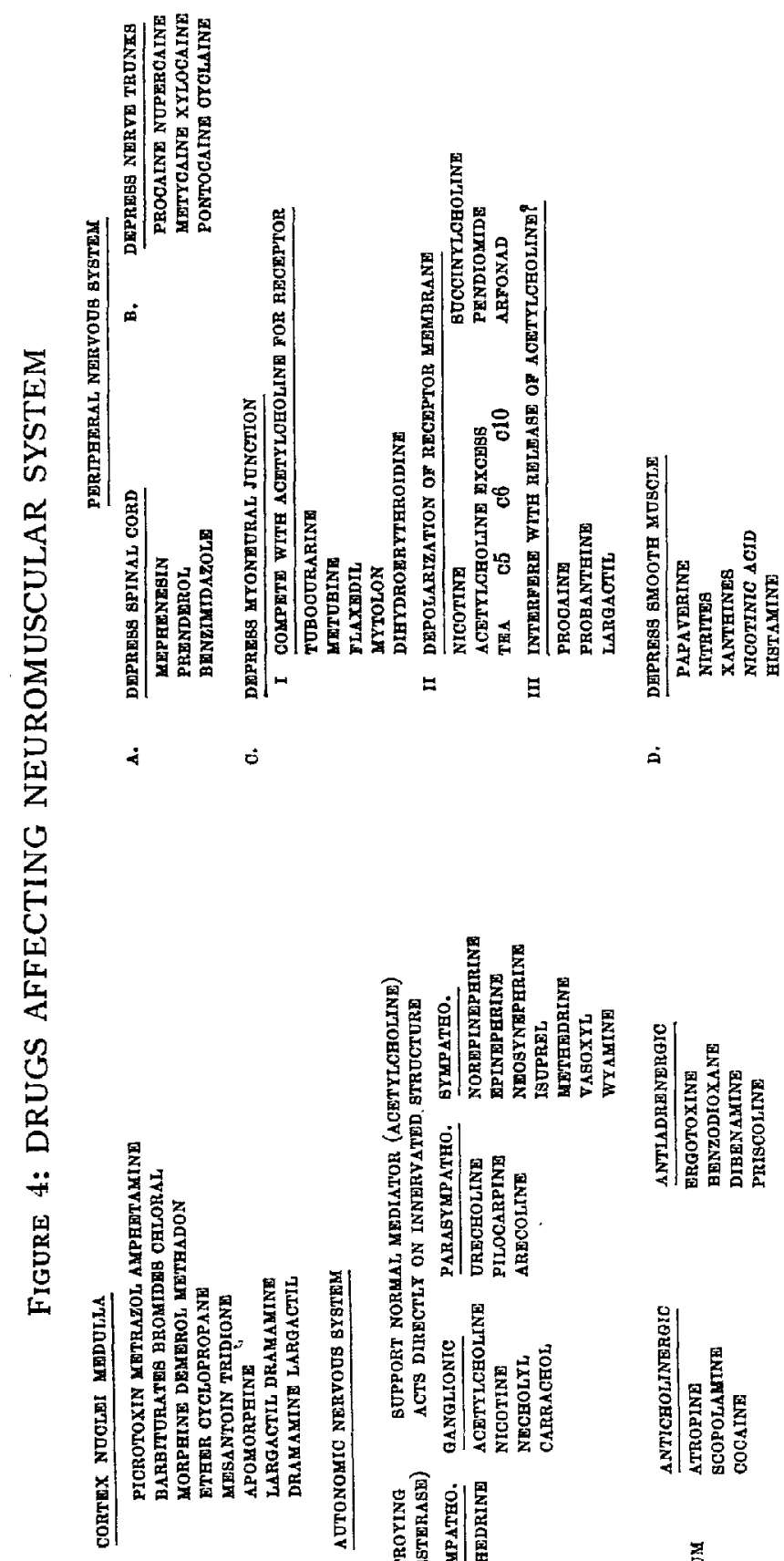

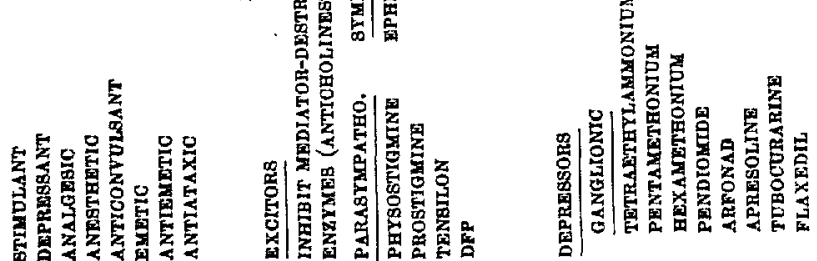
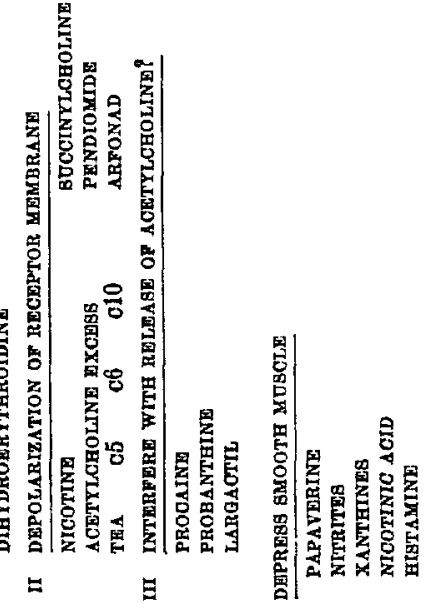
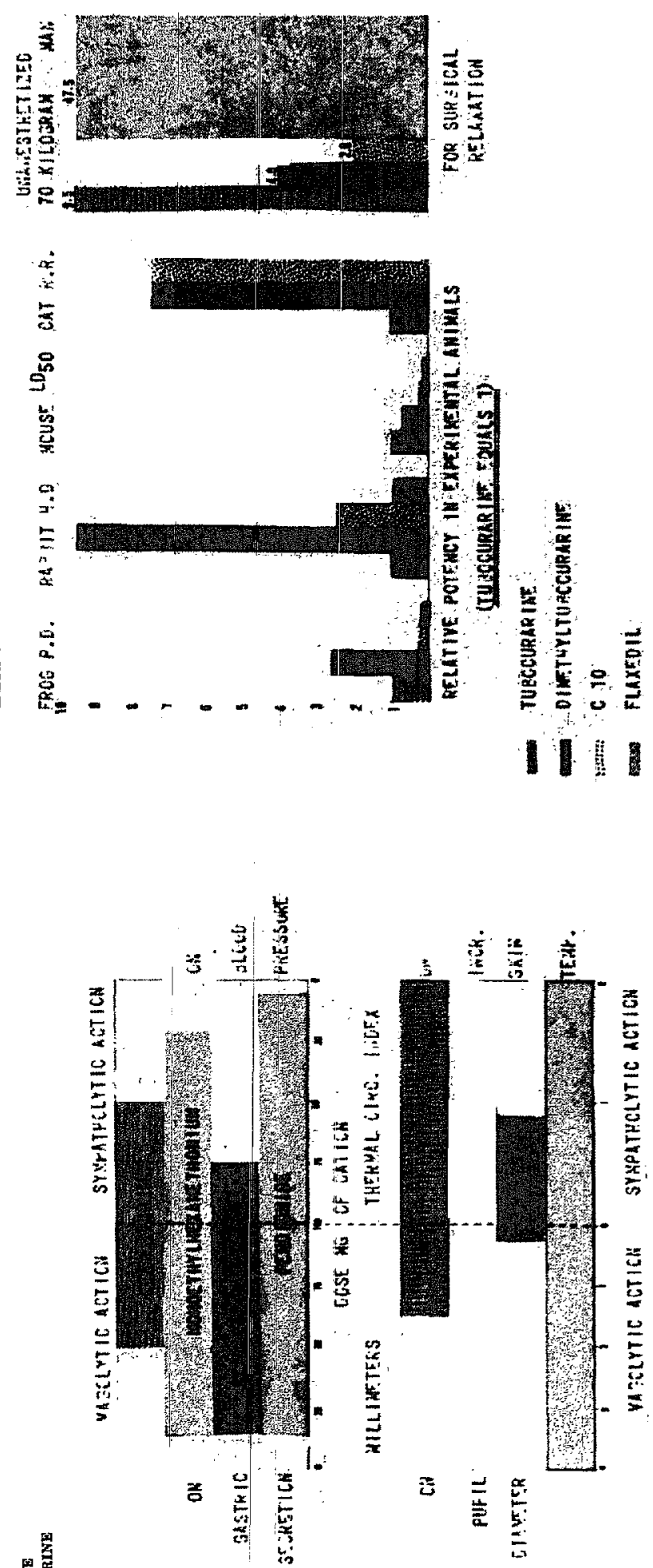
GILBERT et al.: INVESTIGATION OF NE'N DRUGS

FIGURE 5

PATHOLOGICAL EFFECTS OF ANAESTHETIC DRUGS

SITE

ETIOLOGY

EFFECT

\begin{tabular}{|c|c|c|}
\hline BRAIN & $\begin{array}{l}\text { TOXICITY } \\
\text { HYPOTENSION } \\
\text { ANOXIA } \\
\text { ISCHAEMIA }\end{array}$ & $\begin{array}{l}\text { CONVULSIONS } \\
\text { MENTAL IMPAIRMENT }\end{array}$ \\
\hline HEART & $\begin{array}{l}\text { TOXICITY } \\
\text { HYPOTENSION } \\
\text { ANOXIA } \\
\text { REFLEX ISCHAEMIA }\end{array}$ & $\begin{array}{l}\text { ARRHYTHMIA } \\
\text { FIBRILLATION } \\
\text { BLOCK } \\
\text { CONGESTIVE FAILURE } \\
\text { INFARCTION } \\
\text { THROMBOEMBOLISM }\end{array}$ \\
\hline LUNG & $\begin{array}{l}\text { ALLERGY (HISTAMINE) } \\
\text { OBSTRUCTION } \\
\text { ASPIRATION }\end{array}$ & $\begin{array}{l}\text { BRONCHOSPASM } \\
\text { ATELECTASIS } \\
\text { EDEMA } \\
\text { PNEUMONITIS }\end{array}$ \\
\hline LIVER & $\begin{array}{l}\text { HYPOTENSION } \\
\text { (HEMORRHAGE) } \\
\text { ANOXIA } \\
\text { TOXICITY }\end{array}$ & $\begin{array}{l}\text { SHOCK (HEPATITIS) } \\
\text { NECROSIS }\end{array}$ \\
\hline KIDNEY & $\begin{array}{l}\text { HYPOTENSION } \\
\text { ANOXIA } \\
\text { TOXICITY } \\
\text { TRANSFUSION } \\
\quad \text { REACTION }\end{array}$ & $\begin{array}{l}\text { GLOMERULONEPHRITIS } \\
\text { LOWER NEPHRON } \\
\text { BLOCK }\end{array}$ \\
\hline NERVE MUSCLE & $\begin{array}{l}\text { FAULTY POSTURING } \\
\text { TOXICITY }\end{array}$ & PARESIS \\
\hline TARGET ORGAN & $\begin{array}{l}\text { SURGERY } \\
\text { SEPSIS }\end{array}$ & $\begin{array}{l}\text { TRAUMA } \\
\text { INFECTION }\end{array}$ \\
\hline
\end{tabular}

Parasympathetic Nervous System

Largactal has been stated to be vagolytic. In some respects it may be, but in others it is not.

Gastric secretions were shown to be much diminished after Largactil but following the use of insulin there is a rise in gastric secretion and blood sugar. This suggested that there was no vagal block to gastric secretion.

\section{Premedication}

The data of Cohen and Beecher (16) were used in the assay of the use of Largactil for premedication. The clinical results of our studies have already been published (5). They suggested important features to be gained, under many circumstances, prior to operation, during operation, and following it.

These results have since been co-ordinated with experimental work, carried out with the invaluable aid of Dr. K. I. Melville ( 7 ). The main objects of this 
were to follow the responses of vasopressors after the use of Largactil, to investigate the reversal effect of the action of adrenalin, and to assess the ability of Largactil to protect the mechanism of the heart action, under a variety of circumstances.

\section{SUMMARY}

Suggestions concerning the investigation of drugs by a department of anaesthesia have been made.

Claims $(17,18,19,20,21,22,23)$ of a relatıvely new phenothiazine derivative, Largactil, have in some ways been substantrated, in others modified.

It is hoped that the pre-existing clinical data $(24,25,26)$ have been augmented.

\section{RÉSUMÉ}

Beaucoup d'anesthésistes préconısent l'emploi avec soin et consıdération de médicaments et de technıques anesthésiques nouvelles en ce qui concerne la morbidité. Des progrès peuvent être faits par le maintien de vues prudentes et la conduite dans la recherche doit suivre des lignes traditionnelles bien établies. Des technıques, des drogues et des idées nouvelles se présentent et disparaissent. Ces innovations, à la longue, trouvent leur juste nıveau d'utlité. Une nouvelle drogue, si elle est utıle, doit avoir une action précise et voulue, une faible toxicité, doit être manıble et reversıble, elle doit présenter peu de complications et on doit les pouvoir résoudre facilement et d'une manère rationnelle. Ayant satisfait ces critères la nouvelle drogue doit ềtre au moins aussi bonne que ses contreparties existantes

L'action de la nouvelle drogue dort être étudiée d'abord sur des anımaux, et plus tard avec prudence sur des sujets humains. Son action précise sur le fonctoonnement des dufférents organes et systèmes du corps humain doit être soigneusement évaluée. Les effets pathologiques doivent être observés avec soin.

Les auteurs ont entrepris l'étude du Largactil suivant les bases indiquées. Ils ont montré que la fréquence des mouvements respiratorres peut être accélérée mais le volume par minute est considérablement dıminué. On a aussi trouvé que le métabolisme, étant mesuré par la consommation d'oxygène, n'a pas été déprimé. On a établi que le Largactıl est un pussant abaisseur du système sympathique nerveux, et qu'il produit une dilatation vasculaire périphérique égale à celle produite par le bloc lombaire sympathique ou anesthésie lombaire. Les auteurs n'ont pas pu démontrer une action vagolythique imputable à la drogue mais sa valeur comme agent de prémédication avant l'opération a été établie.

\section{REFERENCES}

1. Gilbent, R G. B C M.A J 66.267 (1952).

2 Hewer, C. Langton Brit M. J 142 (1954).

3. Gillespie, Noel, A. Endotracheal Anaesthesia, p 10. 2nd ed, Universily of Wisconsin Press (1948)

4 Dobkin, A B, Lamoureux, L, Letienne, R, \& Gilbert, R G B C M A J , 70626 (1954). 
5 Dobmin, A B., Lamoureux, L., \& Gmbert, R. G. B. Physiological Changes associated with the Clinical Administration of Largactil. Anaesthesia 9157 (1954).

6 - - Conservative Therapy of Peripheral Vascular Disease with the Use of Largactil. Treat. Services Bull 9.324 (1954)

7. Dobkin, A B, Gilbert, R G B, \& Melville, K I. Clinical and Laboratory Evaluation of Chlorpromazine in Premedication Anesthesiology (in press)

8. Mannheimer, W, Pizzolato, P, \& Adriani, J J A M A 15429 (1954)

9 Brittingham, T. E, Berlin, L N, \& WolfF, H G J.A M A. 154329 (1954)

10 Calesnick, B, Smith, N H, \& Beutner, R J Pharm \& Exper Therap 102138 (1951)

11 Vogr, M J Physiol 123451 (1954).

12. Arduini, A. \& Arduini, M D J Pharm \& Exper Therap 11076 (1954)

13. French, J. D., Verzeano, M, \& Magoun, H W Arch Neurol \& Psychiat. 69:519 (1953).

14 Paton, W D M Anaesthesia 8151 (1953)

15 Adpiani, J The Pharmacology of Anesthetic Drugs, pp 10, 11 2nd ed, Springfield, Jill.. Charles C Thomas

16 Cohen, E N \& Beecher, H K J A M A. 147 1664 (1951)

17 Halperin, B N Arch internat de pharmacodyn et de thérap. 74 84, 314 (1947).

18 Bovet, D. \& Longo, V G J. Pharm \& Exper. Therap 102.22 (1951).

19 Dahlbom, R, Diamant, H, Edlund, T, Ekstrand, $\mathrm{T}$ \& Holmstedt, B. Acta pharmacol et toxicol 9163 (1953).

20 Dahlbom, R, Edlund, T, Exstrand, T, \& Lohi, A Acta pharmacol et toxicol. 9168 (1953)

21 Hutcheon, D E J Pharm \& Exper Therap 108340 (1953)

22. Counvoisier, $S$, Fournel, J, Ducrot, $R$, Kolski, $M$, \& Koetschet, $P$ Arch internat de pharmacodyn et de thérap 92305 (1953).

23 Brand, E D, Harris, T D, Borison, H L, \& Goodman, L S J Pharm \& Exper Therap 11086 (1954).

24 Hudon, F \& Jacques, A. Paper read before the I A R.S, Quebec City (1953).

25 Letienne, R \& Lamouneux, L. Personal communication (1954)

26 Baxter, R. W, Bolster, J A, \& McKecknie, S Anaesthesia 979 (1954) 